\title{
Banking Law Symposium, regulatory responses to the global financial crisis: back to the future or back to the past? In honour of Professor David G. Mayes
}

\author{
Rodrigo Olivares-Caminal ${ }^{1} \cdot$ Dalvinder Singh ${ }^{2} \cdot$ Geoffrey Wood ${ }^{3}$
}

Published online: 22 February 2020

(c) Springer Nature Limited 2020

The Banking Symposium, April 2018, held at the Business School, University of Auckland, was intended to be a Festschrift in honour of Professor David Mayes' impending retirement. Sadly, David passed away before the event in November 2017 after a short illness. This collection of papers illustrates the range of interests David had in the area of financial stability, banking supervision and bank resolution. The papers in this collection are partway inspired by some of David's own thoughts and writings on the topics. These themes were thoughtfully combined for the event to evaluate some of the reforms introduced after the GFC. David's work will continue to inspire lots of questions in the field of financial stability, bank supervision and bank resolution. David was a very good friend to us all and is missed. His work will continue to influence and shape our thinking.

The first paper titled 'Two Stabilities: Friends, Good Friends, or inseparable?' by Forest Capie, Terence Mills and Geoffrey Wood, utilises existing data to argue that monetary and financial stability are symbiotic. Using Britain as a case

Dalvinder would like to thank Dr. Nkechikwu Valerie Azinge, Lecturer in Law, University of Lincoln for valuable research assistance.

\footnotetext{
Dalvinder Singh

Dalvinder.Singh@warwick.ac.uk

Rodrigo Olivares-Caminal

r.olivares-caminal@qmul.ac.uk

Geoffrey Wood

geoffrey.wood@buckingham.ac.uk

1 Centre for Commercial Law Studies, Queen Mary University of London, 67-69 Lincoln's Inn Fields, London WC2A 3JB, UK

2 School of Law, University of Warwick, Gibbet Hill Road, Coventry CV4 7AL, UK

3 Economics and International Studies, University of Buckingham, Hunter Street, Buckingham MK18 1EG, UK
}

study, they illustrate that given its effects on banks' balance sheet, monetary stability promotes financial stability. Conversely, financial stability, by stabilising components of the money multiplier, facilitates the attainment of monetary stability. The authors, however, recognise that their findings are limited to their use of the words 'financial stability' in a traditional sense and observe that using it in another sense may lead to varying findings. Dirk Schoenmaker, in his paper titled 'Trans-Tasman Cooperation in Banking Supervision and Resolution' considers whether there is an increased need for banking supervision and resolution in light of the emergence of international banks. Schoenmaker's paper uses the financial trilemma model to explore the options for cooperation between the Australian and New Zealand banking authorities in supervision and resolution given their varying regulatory approaches. It concludes that, to maintain financial stability, supervisors and resolution authorities from home and host countries would need to cooperate, particularly when banks experience problems. Consequently, it proposes the institution of a bilateral treaty for the supervision of the big four Australian banks and joint resolution based on burden sharing between the Australian and New Zealand government. This proposal is considered a stronger alternative to the current crisis resolution framework. Ross Buckley, Douglas Arner and Dirk Zetzsche and Rolf Weber, in their paper, 'The Road to RegTech: The (Astonishing) Example of the European Union' contend that whilst the EU's financial technological advancement and regulation was uncoordinated, it presents a roadmap for other countries to impose coordinated legal and regulatory approaches on finance, data and their interaction. It argues that the advancement of synchronised systems of data, finance and technology has occasioned the increasing use of technology for compliance, monitoring, enforcement and systems designs. Consequently, it suggests that RegTech will pose regulatory and supervisory challenges but also opportunities for improvement. Eva Hüpkes, in the paper 'Resolution (R) 
evolution: Where Have We Come From? Where Might We Go?' reviews the evolution of policies for the management and resolution of cross-border bank failures of the large global financial institutions. Hüpkes argues that irrespective of the substantial progress made, resolution plans have yet to reach a steady state. Hüpkes contends that significant technical and operational aspects still remain to be addressed to ensure that resolution plans can be executed expertly, particular with respect to digital technologies which come with their own challenges. Jens-Hinrich Binder in the paper 'Bank bail-in and disputed claims: Can it cope? The case for and against a vis attractiva resolutionis' examines the treatment of the disputed claims of bail-ins of liabilities and argues that disputed liabilities, especially in cases of large claims' will impact on the calibration of the bail-in tool. Consequently, the article examines how the resulting problems are examined under the BRRD and SRM regulation. It contends that disputed claims cannot adequately be resolved within the valuation and calibration procedure, given the special nature of resolution as an instrument to protect the public interest in the preservation of financial stability and the protection of public budgets. Consequently, it argues that the bail-in tool should be reserved to pre-defined, designated bail-inable instruments. Tobias Tröger in his paper entitled, 'Why MREL Won't Help Much: Minimum Requirements for Bail-In Capital as An Insufficient Remedy for Defunct Private Sector Involvement (PSI) Under the European Bank Resolution Framework' argues that the minimum requirements for own funds and eligible liabilities (MREL) instituted as a workable remedy for bail-in still suffers from similar shortcomings given the complexity, occasioning discretion and lack of predictability, especially with regards PSI principles. This has implications for investors in bail-in debt as the pricing of MREL instruments does not reflect accurate risk assessments of investors, due to the many discretionary choices a multitude of agencies that are supposed to encounter in the administration of the new regime. To buttresses its arguments this paper engages in a doctrinal evaluation of the regulatory objectives of the BRRD's prescriptions for MREL and their implementation in the European Supervision and Resolution Framework. It concludes with policy recommendations which are based on factual analysis. The penultimate paper by Larry Wall, titled 'Is stricter regulation of incentive compensation the missing piece?' provides a cautionary note about the benefits of stricter remuneration schemes to minimise financial stability. Wall argues, it is one more necessary tool in the toolbox to modify bank behaviour and minimise the risk of financial stability. Finally, Kevin Davis in his paper titled 'The Regulatory Changes to Bank Liability Structures: Implications for Deposit Insurance Design' contends that the traditionally promulgated deposit insurance scheme is of limited relevance to particular types of depositors and insurers, including those recently introduced in the EU and UK that are a form of 'tiered' preference. Rather, the benefits of tiered preference arrangements for insurer risk and market discipline are negated if virtually all bank non-equity funding is insured deposits. The paper argues that where a tiered and insurer preference is adopted, it calls for substantial changes to design and pricing of limited, explicit, deposit insurance arrangements.

Publisher's Note Springer Nature remains neutral with regard to jurisdictional claims in published maps and institutional affiliations. 